\title{
MEKANISME TERJADINYA INFLAMASI DAN STRES OKSIDATIF PADA OBESITAS
}

\author{
Ana Rahmawati \\ Jurusan Biologi, Fakultas Sains dan Teknologi \\ Universitas Islam Negeri (UIN) Maulana Malik Ibrahim Malang \\ Email : $\underline{\text { rahma_na@yahoo.com }}$
}

\begin{abstract}
Obesity is a predisposing factor for metabolic syndrome that increases the risk of development of chronic diseases such as type 2 Diabetes Mellitus and atherosclerosis. Obesity is associated with a chronic inflammatory condition with progressive infiltration of immune cells in the adipose tissue of obesity. Adipose tissue is not only a triglyceride storage organ, but studies have shown the role of white adipose tissue as a producer of adipokines. Besides adipokines, also found several inflammatory mediators, such as interleukin-6 (IL-6). Adipokines have the function of regulating food intake, thus providing a direct effect on weight control. It is played by leptin, which is working on the limbic system by stimulating the uptake of dopamine, creating a feeling of fullness. But these adipokines induces production of reactive oxygen species (ROS), resulting in a process known as oxidative stress $(O S)$. There are several mechanisms in producing the oxidative stress. The first is the oxidation of mitochondrial and peroxisomal fatty acid oxidation, which can generate ROS in the oxidation reaction, whereas other mechanisms is over-consumption of oxygen, which generates free radicals in the mitochondrial respiratory chain were found together with oxidative phosphorylation in the mitochondria. High fat diet also capable of generating ROS because it can alter the oxygen metabolism.
\end{abstract}

\section{Pendahuluan}

Selama dua puluh tahun terakhir telah terjadi peningkatan pesat dalam prevalensi obesitas akibat konsumsi diet tinggi lemak dan gaya hidup. Menurut WHO tingkat obesitas telah mencapai proporsi epidemi di seluruh dunia dengan sekitar 2,3 miliar orang dewasa diperkirakan akan kelebihan berat badan atau obesitas pada tahun 2015. Obesitas merupakan faktor risiko yang signifikan sebagai faktor predisposisi terjadinya sindrom metabolik, termasuk intoleransi glukosa, hipertensi, dislipidemia, obesitas sentral, fatty liver dan resistensi insulin. Sindrom metabolik meningkatkan risiko perkembangan penyakit kronis seperti diabetes tipe 2 mellitus dan aterosklerosis. Obesitas juga meningkatkan beban ekonomi yang signifikan dalam biaya perawatan kesehatan (Sanchez et al,2011).

Obesitas dikaitkan dengan kondisi inflamasi kronis tingkat rendah dengan infiltrasi progresif sel-sel imun pada jaringan adiposa obesitas. Sitokin yang dikeluarkan sel imun dan adipokines jaringan adiposa meningkatkan inflamasi jaringan dan selanjutnya menginduksi resistensi insulin.Obesitas adalah penyakit kronis dengan penyebab multifaktorial dan dapat didefinisikan sebagai peningkatan akumulasi lemak tubuh. Jaringan adiposa bukan hanya organ penyimpanan trigliserida, namun penelitian telah menunjukkan peran jaringan white adiposa sebagai penghasil zat bioaktif tertentu yang disebut adipokines. Selain adipokines, juga ditemukan beberapa mediator inflamasi, seperti Interleukin-6 (IL-6). Salah satu Adipokines yaitu leptin, bekerja pada sistem limbik dengan merangsang penyerapan dopamin, menciptakan perasaan kenyang. Namun, adipokines ini menginduksi produksi spesies oksigen reaktif (ROS), menghasilkan proses yang dikenal sebagai stres oksidatif (OS). Karena 
jaringan adiposa adalah organ yang mengeluarkan adipokines dan hal ini pada gilirannya menghasilkan ROS, jaringan adiposa dianggap sebagai faktor independen pada produksi OS sistemik. Ada beberapa mekanisme pada obesitas dalam memproduksi OS. Yang pertama adalah oksidasi mitokondria dan oksidasi peroxisomal asam lemak, yang dapat menghasilkan ROS dalam reaksi oksidasi, sedangkan mekanisme lain adalah overkonsumsi oksigen, yang menghasilkan radikal bebas dalam rantai pernapasan mitokondria yang ditemukan bersama dengan fosforilasi oksidatif dalam mitokondria. Diet kaya lemak juga mampu menghasilkan ROS karena hal itu dapat mengubah metabolisme oksigen. Setelah peningkatan jaringan adiposa, aktivitas enzim antioksidan seperti superoksida dismutase (SOD), katalase (CAT), dan glutation peroksidase (GPx), ditemukan secara signifikan berkurang. Akhirnya, produksi ROS tinggi dan kapasitas antioksidan yang menurun menyebabkan berbagai kelainan, di antaranya dapat terjadi disfungsi endotel, yang ditandai dengan penurunan bioavailabilitas vasodilatasi endotel dan OS sistemik terutama oksida nitrat (NO), serta peningkatan faktor kontraktil endotelium yang mendukung terjadinya penyakit aterosklerosis(Sanchez et al,2011).

\section{Etiologi Obesitas}

Obesitas adalah penyakit kronis dengan penyebab multifaktorial yang berkembang dari interaksi faktor-faktor sosial, perilaku, psikologis, metabolik, selular, dan molekuler (Sanchez et al,2011). Hal ini adalah kondisi di mana jaringan adiposa meningkat dan dapat didefinisikan sebagai peningkatan berat badan yang merupakan hasil akumulasi lemak yang berlebihan. Organisasi Kesehatan Dunia (WHO) mendefinisikan obesitas yaitu indeks massa tubuh (BMI)> 30 dan mendefinisikan overweight yaitu $\mathrm{BMI}=25$ (Sikaris,2004).
Obesitas pada dasarnya adalah akumulasi berlebihan dari triasilgliserol dalam jaringan lemak yang merupakan hasil asupan energi yang berlebihan dibandingkan dengan penggunaan energi. Terdapat hipotesis dasar penyebab penyakit yaitu thrifty gene theory, yang menunjukkan bahwa beberapa populasi mungkin memiliki gen yang menentukan peningkatan penyimpanan lemak, yang pada kondisi lapar akan memberikan manfaat bagi kelangsungan hidup, tetapi dalam keadaan saat ini, kelebihan penyimpanan lemak menghasilkan obesitas dan diabetes melitus tipe 2 (DMT2)(Sikaris,2004)).

Perubahan gaya hidup dan diet telah mengakibatkan peningkatan jumlah obesitas. Teori lain yang menjelaskan perkembangan obesitas yakni bahwa gizi buruk ibu dan pertumbuhan janin yang buruk merupakan faktor risiko untuk terjadinya penyakit kronis yang mempengaruhi pemrograman struktur tubuh, fisiologi, dan metabolisme. Sistem saraf pusat (SSP), melalui sinyal-sinyal, mengatur nafsu makan, asupan energi, dan kenaikan berat badan, obesitas dapat disebabkan oleh kegagalan jalur sinyal ini (Sikaris,2004)).

\section{Jaringan adiposa}

Jaringan adiposa manusia dibagi menjadi jaringan adiposa coklat, yang memiliki adipocytes multilokular dengan mitokondria yang banyak dan mengekspresikan sejumlah besar uncoupling protein 1 (UCP-1), yang bertanggung jawab untuk kegiatan termogenik jaringan ini, dan jaringan adiposa putih, yang bertanggung jawab untuk penyimpanan lemak. Di antara karakteristik jaringan adiposa putih,ditemukan bahwa jaringan tersebut terdiri dari jenis sel yang berbeda seperti fibroblas, preadipocytes, adiposit matang, dan makrofag. Jaringan ini sangat heterogen tergantung lokasi visceral atau subkutan (Sanchez et al,2011). 
Pada hewan coba dengan obesitas, ada peningkatan besar dalam deposit lemak putih karena hiperplasis dan hipertrofi adipositnya. Jaringan adiposa bukan hanya penyimpanan trigliserida (TG), penelitian dalam beberapa tahun terakhir telah menunjukkan peran jaringan adiposa putih sebagai penghasil zat tertentu dengan aktivitas endokrin, parakrin, dan autokrin
(Sikaris,2004). Zat-zat bioaktif ini adalah adipokines atau adipocytokines, di antaranya ditemukan plasminogen activator inhibitor-1 (PAI-1), tumor necrosis factoralpha (TNF- $\alpha$ ), resistin, leptin, adiponektin. Zat-zat ini terutama berasal dari jaringan adiposa putih dan berperan dalam homeostasis berbagai proses fisiologis (Gambar 1).

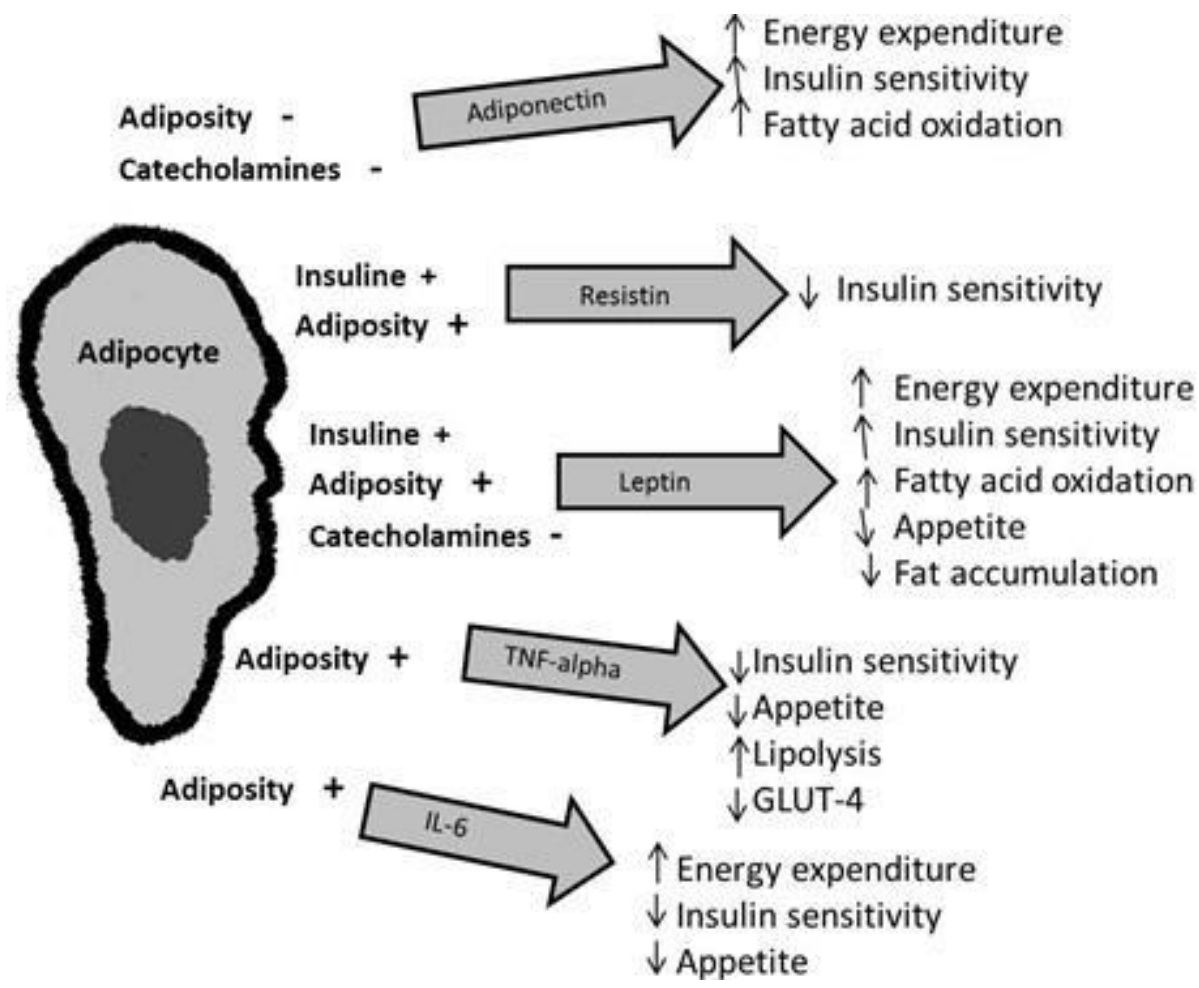

Gambar 1. Gambar ini menunjukkan adipokines utama dan perannya. Jaringan adiposa menghasilkan beberapa adipokines yang memberi efek metabolik, baik di pusat maupun di jaringan perifer. Produksi adipokines ini diatur oleh insulin, cathecholamines, dan adipositas. TNF-alpha: Tumor necrosis factor-alpha; IL-6: Interleukin. (Sanchez et al,2011)

\section{Adipokines dan Homeostasis Metabolik}

1. Leptin

Leptin adalah hormon yang dikeluarkan terutama oleh adiposit dalam kadar yang berhubungan langsung dengan kandungan trigliserida jaringan adiposa dan kondisi gizi. Setelah disekresikan oleh jaringan adiposa, leptin beredar dalam plasma terikat pada protein plasma, masuk secara difusi ke dalam sistem saraf pusat. Dalam inti ventro-medial hipotalamus, leptin merangsang reseptor sitokin kinase 2 (CK2), sintesis hormon yang menstimulasi melanosit dan oleh molekul transkriptor yang meregulasi kokain-amphetamine (CART), melalui parakrin, merangsang reseptor 3 dan 4 dari inti melanocortin lateral, menyebabkan kenyang (Sikaris,2004).

Leptin juga dapat diproduksi dalam plasenta, sumsum tulang belakang, lambung, otot, dan mungkin di otak, yang meningkatkan peran regulasi hormon ini (Sikaris,2004).

Leptin menghambat lipogenesis dan merangsang lipolisis, mengurangi 
tingkat lipid intraseluler di otot rangka, hati, dan sel-sel beta pankreas, sehingga meningkatkan sensitivitas insulin. Pada sistem limbik merangsang reuptake dopamin, sehingga menghalangi keinginan makan dan melalui inti locus coeruleus, mengaktifkan sistem saraf simpatik, yang menyebabkan peningkatan pengeluaran energi (Sanchez et al,2011).

$$
\text { Katekolamin mempengaruhi }
$$

produksi leptin, dan regulator produksi leptin lainnya yaitu glukokortikoid, meskipun telah diketahui bahwa penentu utama sekresi leptin adalah metabolisme glukosa, karena konsentrasi leptin berkurang saat puasa atau kondisi pembatasan kalori dan meningkat sebagai respon terhadap asupan makanan. Obesitas dikaitkan dengan peningkatan kadar leptin. Dalam peradangan, leptin bekerja langsung pada makrofag untuk meningkatkan aktivitas fagosit, dan produksi sitokin proinflamasi juga memberikan efek pada Tsel, monosit, neutrofil, dan sel endotel. Ketika leptin diberikan,terjadi peningkatan kadar protein C-reaktif (CRP), sehingga membuktikan efek inflamasi. Ketika ada penurunan berat badan, tingkat sirkulasi hormon berkurang, dan pada gilirannya, akan mengurangi kadar marker inflamasi plasma terkait obesitas. Selain menyebabkan stres oksidatif dan peradangan pembuluh darah, leptin merangsang proliferasi dan migrasi sel endotel dan sel otot polos, sehingga mendukung perkembangan aterosklerosis. (Sanchez et al,2011).

\section{Tumor Necrosis Factor Alpha $(\mathrm{TNF}-\alpha)$}

TNF- $\alpha$ adalah salah satu sitokin yang pertama kali diidentifikasi dan terlibat dalam respon inflamasi sistemik, selain itu juga telah dikaitkan dengan perkembangan resistensi insulin, obesitas, dan diabetes. Hal ini diproduksi terutama oleh monosit, limfosit, jaringan adiposa, dan otot dan berperan dalam patogenesis sindrom metabolik terkait obesitas (Ouchi et al,2011).
Aktivitas TNF- $\alpha$ pada resistensi insulin yaitu meningkatkan pelepasan asam lemak bebas (FFA) di adipocytes, blok sintesis adiponektin, yang memiliki aktivitas insulin-sensitizing dalam konsentrasi tinggi dalam jaringan adiposa, dan mengganggu aktivitas fosforilasi residu tirosin dalam substrat pertama dari reseptor insulin, yang diperlukan untuk perkembangan sinyal intraseluler hormon. TNF- $\alpha$ mengaktifkan NF- $\alpha$ B, mengakibatkan peningkatan ekspresi molekul adhesi pada permukaan sel endotel dan sel otot polos pembuluh darah, sehingga menimbulkan inflamasi di jaringan adiposa, disfungsi endotel dan akhirnya aterogenesis(Sanchez et al,2011).

3. Interleukin 6 (IL-6)

Sitokin ini memberikan banyak efek, mulai dari pertahanan inflamasi dan kerusakan jaringan. Hal ini dihasilkan baik oleh makrofag dan adiposit, dan oleh selsel sistem kekebalan tubuh, fibroblas, sel endotel, dan otot rangka. Tingkat sirkulasi IL-6 berkorelasi dengan BMI, resistensi insulin, dan intoleransi terhadap karbohidrat. IL-6 juga mempengaruhi toleransi glukosa melalui peraturan negatif visfatin, di samping itu, antagonis sekresi adiponektin, dan dalam model hewan coba didapatkan juga meningkatkan kadar trigliserida meningkatkan gluconeogensis dan glikogenolisis dan menghambat glikogenesis (Sanchez et al, 2011).

4. Angiotensinogen/PAI-1

Plasminogen activator inhibitor

(PAI-1) adalah inhibitor fisiologis pertama aktivator plasminogen dalam darah dan berkontribusi terhadap pembentukan trombus dan perkembangan penyakit kardiovaskular kronis. PAI-1 dapat memainkan peran penting dalam regulasi suplai darah jaringan adiposa dan peredaran asam lemak. Level PAI-1 plasma diatur oleh penumpukan lemak visceral, dan konsentrasi tinggi PAI-1 berhubungan dengan resistensi insulin dan berhubungan dengan sitokin pro-inflamasi (Sikaris,2004).

5. Adiponektin 
Adiponektin adalah protein yang secara struktural homolog dengan kolagen VIII dan $\mathrm{X}$ dan faktor sistem komplemen C1q. Ekspresi dan sekresi adiponektin unik untuk membedakan adiposit dan memiliki aktivitas regulasi pada homeostasis energi,metabolisme glukosa dan lipid, dan aktivitas anti-inflamasi. Berbeda dengan adipokines lain, ekspresi adiponektin dan konsentrasinya dalam plasma tidak meningkat, tetapi agak menurun dalam berbagai macam penyakit karena resistensi insulin dan obesitas. Adiponektin meningkatkan sensitivitas insulin, mengurangi aliran asam lemak bebas dan meningkatkan oksidasi, menghambat enzim hati, mengurangi pelepasan glukosa hepatik dan otot, dan menstimulasi penggunaan glukosa dan oksidasi asam lemak. Adiponektin menunjukkan aktivitas antiinflamasi yang tinggi dan antiatherogenic tinggi karena menghambat adhesi monosit ke sel endotel, transformasi makrofag menjadi sel busa dan aktivasi sel endotel, menghambat ekspresi TNF- $\alpha$, mengurangi tingkat CRP, dan meningkatkan produksi nitric oxide ( NO) pada sel endotel. Globular isoform menghambat proliferasi sel dan produksi ROS yang disebabkan oleh oksidasi low-density lipoprotein (LDL) selama pembentukan plak ateromatosa. Secara umum, akibat defisiensi adiponektin dalam reduksi NO pada dinding pembuluh darah dan meningkatkan adhesi leukosit, menyebabkan peradangan pembuluh darah kronis. Akhirnya, dapat diamati bahwa bahwa TNF- $\alpha$ dan IL-6 berpotensi menghambat ekspresi adiponektin dan sekresi (Sanchez et al,2011).

\section{Adipsin}

Adipsin adalah protease serin yang relatif kecil yang disekresikan oleh sel lemak dan yang berhubungan positif dengan adipositas, resistensi insulin, dislipidemia, dan penyakit kardiovaskular. Adipsin muncul untuk mengatur tingkat asam lemak dari Lipoprotein lipase (LPL) yang diambil oleh adipocytes dan kemudian diubah menjadi TG. Dasar molekuler patogenesis gangguan obesitas terkait adipsin belum sepenuhnya dijelaskan. Jaringan adiposa berfungsi tidak hanya sebagai organ penyimpanan energi, tetapi juga sebagai organ endokrin. Adipsin memiliki fungsi autokrin, parakrin, dan fungsi endokrin. Adipokines seperti adipsin secara biologis adalah molekul aktif yang dihasilkan oleh jaringan adiposa. Adipsin memainkan peran dalam homeostasis energi, dan dalam metabolisme glukosa dan lipid (Sanchez et al,2011).

\section{Resistin}

Resistin adalah adipokine yang diproduksi oleh adiposit matang dan makrofag, dan telah diketahui bahwa resistin terlibat dalam hubungan antara obesitas dan resistensi insulin. Resistin berhubungan dengan inflamasi karena produksi dominan pada monosit dan korelasinya dengan level IL-6 (Fonseca,2007).

Tingkat sirkulasi resistin mengalami penurunan oleh obat anti diabetes rosiglitazone dan meningkat dengan diinduksi diet maupun genetik. Pemberian antibodi anti-resistin meningkatkan gula darah dan aktivitas insulin pada tikus dengan obesitas yang diinduksi diet (Sanchez et al,2011).

\section{Adipokines lainnya}

Konsentrasi adipokine ini meningkat pada manusia dengan obesitas abdominal dan Diabetes melitus. Pengaturan sintesis dirangsang oleh glukokortikoid dan dihambat oleh TNF- $\alpha$, IL-6, hormon pertumbuhan, dan agonis reseptor $\beta$-adrenergik (Sanchez et al,2011).

Visfatin merangsang diferensiasi adiposit, mengakibatkan akumulasi trigliserida dari glukosa, dan menginduksi ekspresi gen yang mengkode untuk diacylglycerol acyltransferase dan adiponektin melalui pengurangan pelepasan glukosa dari adiposit (Fonseca,2007).

Adipokine lain adalah omentin, peptida yang disekresikan oleh lemak visceral, memberikan efek menguntungkan pada penyerapan glukosa, berfungsi sebagai sensitizer insulin, dan dapat bekerja seperti 
insulin (Fonseca,2007). Selain itu terdapat pula apelin,reseptor apelin terdapat dalam otak dan di hampir semua jaringan perifer, terutama pada sel-sel endotel pada jantung, ginjal, paru-paru, adrenal, dan pembuluh endokardium. Apelin menyebabkan terbentuknya NO, vasodilatasi dan vasokonstriksi terkait endotelium melalui aksinya pada sel-sel otot polos (Sanchez et al,2011).

\section{Obesitas dan Stres oksidatif}

Obesitas dapat menyebabkan stres oksidatif sistemik, dikaitkan dengan produksi irreguler adipokine, yang berkontribusi pada perkembangan sindrom metabolik. Sensitivitas CRP dan biomarker lain dari kerusakan oksidatif lebih tinggi pada individu dengan obesitas dan berkorelasi langsung dengan BMI dan persentase lemak tubuh, oksidasi LDL, dan tingkat trigliserida. Sebaliknya, marker antioksidan lebih rendah sesuai dengan jumlah lemak tubuh dan obesitas sentral. Sebuah penelitian menunjukkan bahwa diet tinggi lemak dan karbohidrat menginduksi peningkatan yang signifikan dalam stres oksidatif dan peradangan pada orang dengan obesitas (Sanchez et al,2011).

Mekanisme Pembentukan Radikal Bebas pada Obesitas :

1. Jaringan adiposa

Peningkatan obesitas terkait stres oksidatif terjadi karena adanya jaringan adiposa berlebihan. Telah diketahui bahwa adipocytes dan preadipocytes telah diidentifikasi sebagai sumber sitokin proinflamasi, termasuk TNF- $\alpha$, IL-1, dan IL-6. Sitokin ini adalah stimulator poten untuk produksi oksigen reaktif dan nitrogen oleh makrofag dan monosit. Oleh karena itu, peningkatan konsentrasi sitokin ini dapat meningkatkan stres oksidatif. TNF- $\alpha$ juga meningkatkan interaksi elektron dengan oksigen untuk menghasilkan anion superoksida. Jaringan adiposa juga memiliki kapasitas sekresi angiotensin II, yang merangsang aktivitas oksidasi Nicotinamide adenine dinukleotida fosfat
(NADPH) dan produksi reaktif oksigen species (ROS) di adiposit.

2. Oksidasi Asam Lemak

Oksidasi mitokondria dan oksidasi peroxisomal asam lemak mampu menghasilkan radikal bebas dalam hati oleh karena itu stres oksidatif dapat mengakibatkan perubahan DNA mitokondria dalam fosforilasi oksidatif yang terjadi pada mitokondria dan menyebabkan kelainan struktural dan pengurangan adenosin trifosfat (ATP). Namun, tidak tertutup kemungkinan bahwa kelainan mitokondria telah terjadi sebelumnya yang kemudian menimbulkan kelebihan produksi ROS.

3. Berlebihan konsumsi Oksigen

Obesitas meningkatkan beban mekanik dan metabolisme miokard, oleh karena itu, konsumsi oksigen meningkat. Salah satu konsekuensi negatif dari peningkatan konsumsi oksigen adalah produksi ROS sebagai superoksida, peroksida radikal, dan hidrogen hidroksil yang berasal dari peningkatan respirasi mitokondria dan dari hilangnya elektron yang dihasilkan dalam rantai transpor elektron, yang mengakibatkan pembentukan superoksida radikal.

4. Akumulasi Kerusakan Seluler

Akumulasi lemak yang berlebihan dapat menyebabkan kerusakan sel karena efek tekanan dari sel-sel lemak yaitu, steatohepatitis non alkohol. Kerusakan sel pada gilirannya menyebabkan produksi yang tinggi sitokin seperti TNF- $\alpha$, yang menghasilkan ROS di jaringan, meningkatkan lipid peroksidasi.

\section{Jenis Diet}

Kemungkinan mekanisme lain pembentukan ROS pada obesitas adalah melalui diet. Konsumsi diet tinggi lemak dapat mengubah metabolisme oksigen. Deposit lemak rentan terhadap timbulnya reaksi oksidasi. Jika produksi ROS ini melebihi kapasitas antioksidan sel, stres oksidatif mengakibatkan peroksidasi lipid dan memberikan pengaruh untuk perkembangan aterosklerosis. 
6. Peran Mitokondria dalam Perkembangan stres oksidatif pada Obesitas

Mitokondria memberikan energi yang dibutuhkan untuk hampir semua proses seluler yang pada akhirnya memungkinkan melaksanakan fungsi fisiologis, selain itu mitokondria memegang peran sentral dalam kematian sel dengan mekanisme apoptosis. Disfungsi mitokondria terlibat dalam berbagai penyakit mulai dari penyakit neurodegenerative untuk diabetes dan penuaan. Obesitas mempengaruhi metabolisme mitokondria, yang mendukung pembentukan ROS dan pengembangan stres oksidatif. Di sisi lain, mekanisme lain telah disampaikan yaitu melibatkan efek dari trigliserida tinggi (TG) pada fungsi rantai pernapasan mitokondria, dimana intraseluler TG, yang juga tinggi, menghambat translokasi nukleotida adenin dan mengakibatkan pembentukan superoksida (Sanchez et al,2011).

\section{Obesitas dan Kapasitas Antioksidan}

Ketika obesitas terus berlanjut untuk waktu yang lama, sumber antioksidan dapat menurun, seperti aktivitas enzim seperti superoksida dismutase (SOD) dan katalase (CAT). Aktivitas SOD dan glutathione peroxidase (GPx) pada individu dengan obesitas secara signifikan lebih rendah dibandingkan dengan pada orang sehat. Sebuah penelitian pada tikus menunjukkan bahwa konsentrasi vitamin A pada liver memiliki aktivitas antioksidan secara signifikan lebih rendah pada tikus dengan obesitas dibandingkan dengan yang tidak obesitas, konsentrasi vitamin A pada tikus dengan obesitas menunjukkan dilusi vitamin yang larut dalam lemak pada penyimpanan lipid yang tinggi dihati. Selain vitamin A, kadar antioksidan serum, seperti vitamin $\mathrm{E}$, vitamin $\mathrm{C}$, dan $\beta$-karoten, serta glutathione, menurun pada obesitas. Selain itu ROS menurunkan ekspresi adiponektin, menunjukkan bahwa terapi dengan antioksidan atau ROS inhibitor bisa mengembalikan pengaturan adipokines. Dengan demikian, suplementasi dengan antioksidan akan mengurangi risiko komplikasi yang berkaitan dengan obesitas dan stres oksidatif (Sanchez et al, 2011).

\section{Inflamasi dan Obesitas}

Inflamasi sebagai manifestasi dari peningkatan stres oksidatif, yang meningkat pada seseorang dengan obesitas dan berhubungan dengan resistensi insulin dan disfungsi endotel. Mekanisme inflamasi pada obesitas terkait dengan adanya jaringan adiposa yang memproduksi adipokine dan protein fase akut yang dipicu oleh hipoksia. Hipoksia akan dihasilkan selama pertumbuhan berlebih dari jaringan adiposa selama obesitas. Jaringan adiposa menghasilkan 25\% IL-6 sistemik, sehingga jaringan adiposa ini dapat menyebabkan inflamasi sitemik tingkat rendah pada orang dengan kelebihan lemak tubuh. Bukti menunjukkan bahwa secara keseluruhan, dibandingkan dengan makrofag, sel-sel lemak memiliki kapasitas sama atau lebih besar dari sel-sel inflamasi, dan telah diamati bahwa terjadi peningkatan faktorfaktor yang dikeluarkan oleh adiposit pada inflamasi sistemik. Jaringan adiposa obesitas mengaktifkan CD8(+)T-sel, yang kemudian mengakibatkan perekrutan dan aktivasi makrofag dalam jaringan ini. CD8 (+) T-sel memainkan peran penting dalam inisiasi inflamasi adiposa (Nishimura et al,2009).

\section{Kesimpulan}

Pada obesitas dimana terjadi penyimpanan yang berlebihan dari jaringan adiposa, terjadi peningkatan sekresi adipokine. Selain adipokine, juga ditemukan kelebihan produksi ROS, yang merusak struktur selular dan bersama dengan rendahnya produksi NO memicu terjadi akumulasi progresif lemak dan akhirnya menyebabkan kondisi patologi. Adapun mekanisme pembentukan radikal bebas pada obesitas yakni peningkatan sitokin proinflamasi yang dihasilkan oleh adipocytes dan preadipocytes seperti TNF- 
$\alpha$, IL-1, dan IL-6. Sitokin ini adalah stimulator poten untuk produksi oksigen reaktif dan nitrogen oleh makrofag dan monosit. TNF- $\alpha$ meningkatkan interaksi elektron dengan oksigen untuk menghasilkan anion superoksida. Jaringan adiposa juga memiliki kapasitas sekresi angiotensin II, yang merangsang aktivitas oksidasi Nicotinamide adenine dinukleotida fosfat (NADPH). Oksidasi NADPH berperan utama dalam produksi ROS di adiposit. Selain itu juga melalui oksidasi asam lemak serta peningkatan konsumsi oksigen pada obesitas memicu peningkatan respirasi mitokondria yang menghasilkan superoksida,peroksida radikal dan hidrogen hidroksil.

Penurunan lemak tubuh akan memperbaik marker oksidasi dan meningkatkan aktivitas antioksidan, yang telah rusak dengan obesitas. Oleh karena itu, penurunan berat badan melalui terapi gizi dan farmakologis, selain juga suplementasi dengan nutrisi antioksidan seperti vitamin $\mathrm{E}$, $\mathrm{A}$, dan $\mathrm{C}$, flavonoid, dapat menjadi kunci untuk mengurangi risiko pengembangan kondisi patologi yang berkaitan dengan OS dan obesitas seperti tekanan darah tinggi dan sindrom metabolik.

\section{DAFTAR PUSTAKA}

Fernández Alba, Madrigal Eduardo, Bautista Mirandeli et al., 2011. Inflammation, Oxidative Stress, and Obesity. International Journal of Molecular Sciences. 12, 3117-3132.

Fonseca-Alaniz, M.H., Takada J., AlonsoVale, M.I., Lima, F.B. 2007. Adipose tissue as an endocrine organ: From theory to practice. $J$. Pediatr. 83 (Suppl. 5), S192-S203.

Nishimura, S., Manabe, I., Nagasaki, M., Eto, K., et al.,2009. CD8+effector T cells contribute to macrophage recruitment and adipose tissue inflammation in obesity. Nat. Med. $15,914-920$
Ouchi, N., Parker, J.L., Lugus, J.J., Walsh, K. 2011. Adipokines in inflammation and metabolic disease. Nat. Rev. Immunol. 11, 85-97.

Sikaris, K. 2004. The clinical biochemistry of obesity. Clin. Biochem. 25, 165-181. 